Published version of this article: Lord, N. (2013) 'Responding to transnational corporate bribery using international frameworks for enforcement: anti-bribery and corruption in the UK and Germany' Criminology and Criminal Justice, Published online before print February 6, 2013, doi: 10.1177/1748895812474662 available at: http://cri.sagepub.com/content/early/2013/02/04/1748895812474662.abstract

\title{
Responding to transnational corporate bribery using international frameworks for enforcement: anti-bribery and corruption in the UK and Germany
}

\author{
Nicholas J Lord \\ Cardiff University, UK
}

\begin{abstract}
Transnational corporate bribery is complexly organised at a multi-jurisdictional level. However, enforcement remains at the local, national level where investigators and prosecutors are pressured to respond using frameworks for enforcement created by intergovernmental organisations. These legal frameworks are incorporated into national laws which results in legal convergence between jurisdictions but the 'functional equivalence' approach of intergovernmental organisations enables divergence in enforcement practices. This article analyses two theoretically comparable anti-corruption enforcement systems, those of the UK and Germany, to evidence an understanding of policy responses at the operational level. Irrespective of the enforcement system implemented (centralised or decentralised, use of corporate criminal liability or not, amongst other dimensions), enforcement faces significant structural, legal, procedural, evidential and financial obstacles, even where will to enforce the law is high. Consequently, criminal law enforcement is currently implausible.
\end{abstract}

Corresponding author:

Nicholas James Lord, School of Social Sciences, Glamorgan Building, Cardiff University, King Edward VII Avenue, Cardiff, CF10 3WT.

Tel: +44 (0)2920 876909 Email: lordnj@cardiff.ac.uk 
Keywords

Corporate bribery, corporate corruption, anti-bribery and corruption, criminal prosecution, negotiated justice

Introduction

Large-scale investigations involving multi-national corporations (MNCs) such as the BAE Systems and Siemens bribery scandals demonstrate how large commercial enterprises may be the subject of allegations of bribing overseas public officials to further or maintain their business interests. ${ }^{1}$ For example, BAE Systems are (and have been) under investigation for paying bribes to the Czech Republic, Romania, Qatar, Chile, Tanzania and most notably Saudi Arabia to secure sales of their defence equipment. Some would accept that as the cost of development or the unavoidable interdependence between licit and illicit commerce in 'grey' markets; others would argue that corruption and bribery have devastating consequences, in particular for developing countries where much corporate bribery is directed - such activities may cause serious political, economic, social and environmental harms ${ }^{2}$ such as diminished economic development and growth, increased social inequality, and distrust of government (Delaney, 2007: 419) as well as inefficient government contracting and privatisations, use of delays and red tape to induce payoffs, inefficient use of corrupt payments, inequities in reference to the distribution of gains and losses, damaged political legitimacy, and slowed growth whereby the benefits of development are distributed unequally (Rose-Ackermann, 1997: 42-46). These moral and socio-economic harms have led concerned parties to focus on law enforcement and other control mechanisms. But criminal justice mechanisms have not proven to be easy. 
Since the creation of the Organisation for Economic Cooperation and Development's (OECD) Anti-Bribery Convention 1997 and subsequent pressure for nation-states to conform, such corporate bribery in international business has been placed on the agenda of national governments. Sovereign states that do not have an active enforcement stance against transnational bribery are facing intense criticism from (i) international and intergovernmental organisations such as the OECD and the United Nations (UN) and (ii) international anti-corruption bodies including non-governmental organisations (NGOs) such as Transparency International (TI). International measures such as the OECD Anti-Bribery Convention, the UN Conventions and numerous regional (for example European Union and Council of Europe) level Conventions provide anti-corruption frameworks within which to tackle these crimes - these often incorporate monitoring and evaluation mechanisms (for example, the Group of States against Corruption (GRECO) and the OECD Working Group on Bribery) to review the efficacy of national anti-bribery and corruption policies and enforcement practices, though serious measurement and indeed conceptual issues remain.

However, implementing international frameworks at the national level is not straightforward. For example, while countries sign and ratify such international frameworks, some jurisdictions often possess insufficient infrastructures and resources to enforce them (Shover and Hochstetler, 2006: 107). State corruption may also reduce enforcement while powerful nations may have the ability to influence the creation of international treaties and therefore protect their business activities by resisting criminalisation or refusing to ratify treaties (Michalowski and Bitten, 2005). As business transactions become more transnational in nature, increased opportunities for white-collar crimes and the possibility of externalising risk have been created - the global marketplace also intensifies the impacts of white-collar crimes and risky transactions as we have seen most recently with the global 
economic crisis and subprime mortgage lending (Gibbs et al., 2010: 544). There is no widely accepted nor effective transnational law making and law enforcement body or mechanism in other words, business becomes global but controllers are generally constrained by divergent domestic rules and limited jurisdiction (Passas, 1999: 400; Braithwaite and Drahos, 2000). It is here that a key contradiction becomes evident: in short, national authorities are pressured to respond to trans-national corporate bribery using inter-national frameworks for enforcement that are distanced from context and the cultural and internal/external pressures faced at the operational level.

These issues raise significant questions: To what extent are national enforcement regimes able to implement the requirements of international frameworks? What are the differences and similarities in the challenges and obstacles faced in different jurisdictions? Due to several key intellectual similarities and differences, comparative analysis of the UK and Germany is particularly suitable for understanding the impact of international frameworks for enforcement and the limits and strengths of national enforcement frameworks. ${ }^{3}$ First, both the UK and Germany are key economic players, both being members of the G8 and both having the largest share of world exports in the EU. (This is significant given the focus on transnational corruption). Second, since the introduction of the OECD Convention, Germany has concluded significantly more cases than the UK, although these enforcement rates have become more similar in the last three years. Third, the anti-corruption enforcement systems of the two jurisdictions differ in structure. The UK may be considered a centralised system while the German system is decentralised. Fourth, corporate criminal liability exists in the UK but not in Germany.

The empirical insights and quotes in this article are taken from data collected as part of the author's ESRC funded doctoral research that was completed in 2012. The findings are 
based upon 20 semi-structured bilingual interviews primarily with UK and German investigators and prosecutors. In the UK, due to the centralised nature of anti-corruption enforcement, there is only one main state agency with national jurisdiction (excluding Scotland); this is the Serious Fraud Office (SFO), although other agencies provide assistance (see below). Investigators and prosecutors in the SFO were sampled across different levels of operational and strategic involvement. In Germany the anti-corruption system is decentralised and primary responsibility is located with regional state prosecutors and police, and there are no specialist anti-corruption agencies. Key state actors in two active Bundesländer were approached and acted as gatekeepers to prosecutorial and investigatory agencies and departments. Interviews with those at the operational and strategic levels were carried out. Interviews were also conducted with representatives of two intergovernmental organisations and a leading non-governmental organisation that are highly influential in the response to transnational corporate corruption and bribery. UK and German lawyers with extensive prosecutorial/defence experience of white-collar crimes and country specific experts were also interviewed along with extensive bilingual document analysis. Interviews discussed the policy responses in the two jurisdictions and at the international level with specific focus on detection, investigation, prosecution and prevention and their location within the cultural, institutional and legal contexts of both countries.

The article initially analyses the most significant international enforcement frameworks. Here the OECD and UN Conventions are analysed and their impact at the national level discussed - although much convergence is evident (even though Germany is yet to ratify the UN Convention against Corruption (UNCAC) - see below), significant differences remain. These reflect the 'functional equivalence' approach adopted by 
intergovernmental organisations. However, common difficulties are faced: nation-states attempting to regulate the behaviour of transnational corporations often face a host of political concerns and economic interests (Rothe, 2010: 561; Snider and Bittle, 2011). And as demonstrated here, there are significant structural, legal, evidential, procedural and financial obstacles to implementing international frameworks for enforcement, even when motivation to enforce is high. Consequently, full criminal law enforcement is currently implausible.

\section{International anti-bribery frameworks}

Nation-states strive to promote their own economic and corporate interests. Unless they have key power advantages, creating an even playing field is important for those countries with corporations interested in exporting or investing overseas. In the 1970s, the US government faced internal criticism over the conduct of its corporations in relation to bribery of overseas officials and subsequently enacted the Foreign Corrupt Practices Act 1977 to address this, expecting that other jurisdictions would follow suit. This did not immediately occur, however, and it took two more decades before US pressures led the OECD to create their Anti-Bribery Convention 1997. This required key economic countries to create similar transnational bribery provisions at the national level. The UNCAC 2003 was more complex and organic in its creation and represented the interests of a wider number of stakeholders and jurisdictions. Germany and the UK ratified the OECD Convention in September 1998 and December 1998 respectively. At the time of writing, Germany has yet to ratify the UNCAC but signed it in December 2003. The UK ratified the UNCAC in February 2006. The OECD and UN Conventions are global in scope, albeit the OECD Convention is 
specifically targeted at those countries with the largest share of international exports. Other conventions and provisions exist at the EU level (most notably the Council of Europe and EU conventions and protocols - some of which preceded the UNCAC and OECD Convention). These contain similar provisions to, but are less influential than, the UNCAC and OECD Convention that this article focuses on.

The OECD Anti-Bribery Convention

The OECD Convention was the first and remains the only legally binding instrument focusing on the supply side of bribery of foreign public officials in international business transactions and provides measures to make this effective. The Convention deals with what is termed 'active bribery' in contrast to 'passive bribery'. This means the focus is on the offence committed by the person who promises or gives a bribe. That said, the Convention does not use the term 'active bribery' to avoid creating the wrong impression that the briber always takes the initiative and the recipient is merely a passive victim (OECD, 1997: 14, paragraph 1): it is often the case that the recipient will have induced or pressured the briber and thus be more 'active'. The Convention seeks a 'functional equivalence' amongst the measures taken by the Parties to sanction bribery of foreign public officials. 'Functional equivalence' permits State Parties to implement any means they consider to be suitable providing they enable the requirements of Article 1 of the Convention (The Offence of Bribery of Foreign Public Officials) to be met. Thus, anti-bribery enforcement measures in each jurisdiction do not require uniformity or changes in fundamental principles of a Party's legal systems). For pragmatic and political reasons, there are therefore no requirements for harmonisation of anti-bribery measures across jurisdictions, with 'goals' (e.g. reductions in bribery or 
increased enforcement) being prioritised above 'means' (e.g. the use of corporate criminal liability in the UK but not Germany). This requires greater conceptual analysis of equivalence than mere technical copying would do.

Both the UK and Germany are categorised as 'active enforcers' of the OECD Convention. This refers to those countries with a share of world exports over $2 \%$ and with at least 10 major cases on a cumulative basis, at least three of which were initiated in the last three years and resulted in substantial sanctions - these thresholds are arbitrary and are not premised on any logical foundation (it is unclear why the threshold is 10 major cases, for example). Data taken from the most recent TI Progress Report from 2012 indicate that in the period since the Convention came into force up until the end of 2011, Germany had concluded 176 cases (of which over 16 were 'major') while the UK had concluded 23 cases (all of which were 'major') up until August 2012. ${ }^{4}$ Despite the significant difference in figures, the enforcement rates of major cases and individual prosecutions have become more similar in recent years (the UK concluded its first case in 2008).

The UN Convention against Corruption

The UNCAC is the first global legally binding instrument in the fight against corruption. It requires the States Parties to implement numerous and detailed anti-bribery and corruption measures impacting upon their laws, institutions and practices. The purpose is to aid prevention, detection and sanctioning of corrupt practices and encourage cooperation. The Convention requires States Parties to establish a range of offences associated with corruption and attaches particular importance to prevention and the strengthening of international cooperation to combat corruption. It also includes 'innovative and far- 
reaching' provisions on asset recovery and technical assistance and implementation. It contains eight chapters and 71 articles, in comparison to the OECD Convention that is relatively short with 17 articles. The UNCAC, when compared to other conventions, is more detailed and extensive with its provisions and incorporates an extensive global reach: it was negotiated by representatives of more than a hundred countries from all regions while civil society organisations, such as $\mathrm{TI}$, also had a significant role in this process. The UNCAC goes beyond the scope of the OECD Convention in numerous ways. For example, Articles 15 and 16 require the criminalisation of 'active' and 'passive' bribery of national public officials and foreign public officials respectively. Amongst others, article 21 explicitly incorporates bribery in the private sector into the Convention whilst numerous other offences (for example, embezzlement, abuse of functions, etc.) not included in the OECD Convention are explicitly included in the UNCAC.

\section{The national level: legal frameworks and implementation of international conventions}

The above international conventions provide extensive anti-bribery and corruption frameworks. The external pressure on states to implement relevant legislation is great, but law creation also faces significant internal pressures. Both the UK and Germany have implemented stringent legal provisions for the regulation of transnational corporate bribery providing the enforcement authorities with legal frameworks to investigate and prosecute foreign bribery cases.

The UK 
The UK Bribery Act 2010 (UKBA) that came into force on 1 July 2011 is now the key piece of anti-corruption legislation in the UK. Prior to this (and analogous in some respects to fraud before the Fraud Act 2006), the legal system presented a somewhat complex and fragmented picture of bribery, with several overlapping laws covering specific corruption offences. Anti-bribery and corruption legislation was primarily provided under the Prevention of Corruption Acts 1889 - 1906, with amendments from the Anti-Terrorism, Crime and Security Act 2001. Current transnational corporate bribery cases are largely still being conducted in relation to offences under these acts. At the time of writing, no transnational corporate bribery cases have been brought under the UKBA. The UKBA, however, was developed following significant criticism and pressure at the international level and provides one of the most extensive national anti-bribery laws.

The UKBA contains four distinct offences: the general offences of active (offering, promising) and passive (accepting, soliciting) bribery; the bribery of foreign officials (broad definition including a variety of state officials, for example, politicians, police officers, etc. and must be in the context of business commerce); and the failure of commercial organisations to prevent bribery (a form of strict liability making corporations criminally liable for the actions of their employees, subsidiaries, intermediaries (see below)). UK prosecutors are also able to use a variety of other criminal offences and legislation such as the Proceeds of Crime Act 2002 (POCA) that enables substantive bribery cases to be concluded in relation to money laundering offences, amongst others.

\section{Germany}


The Anti-Corruption Act 1997 was the last measure to improve Germany's criminal law that was solely initiated by German political actors (Wolf, 2006: 785). This Act formulated sections 331 - 338 of the German Criminal Code (GCC). Anti-bribery and corruption legislation is further supplemented by the EU Anti-Bribery Act and the Act on Combating Bribery of Foreign Public Officials in International Business Transactions 1998 - this latter Act satisfies the requirements of the OECD Convention. The Bundestag has largely confined its implementation legislation to the minimum requirements of the respective international legal instruments, a policy that has led to legal inconsistencies (Wolf, 2006: 789). In 2006 the German Federal Ministry of Justice created a governmental draft of a Second AntiCorruption Act intended to bind various international conventions and provisions, including the UNCAC. At the time of writing, this new law has not been enacted. All national provisions on corruption related criminal offences can be located in the GCC, in addition to the abovementioned auxiliary laws. The German GCC distinguishes between Bestechung (active bribery for future or past actions that induced an official to breach their duties) and Bestechlichkeit (passive bribery for past and future actions that induced an official to breach their duties), and Vorteilsannahme (acceptance of an advantage or benefit for future or past actions that did not involve the official breaching their duty) and Vorteilsgewährung (giving of an advantage or benefit for future or past actions that did not involve the official breaching their duty). German prosecutors also utilise a variety of other criminal offences such as 'fraud' and 'breach of trust' to deal with substantive transnational bribery cases.

\section{Legal convergence}


The impact of pressuring nation-states to implement international frameworks for enforcement has led to convergence and harmonisation of key legal provisions. Germany has yet to ratify the UNCAC but this relates to the requirement for the criminalisation of 'domestic bribery', which has attracted opposition from German politicians. ${ }^{5}$ German authorities might regard it as consistent to respond to international obligations, but to regard their domestic legislation as their own business alone. Despite non-ratification, Germany nonetheless meets all the foreign bribery requirements of the UNCAC due to the similar requirements of the ratified OECD Convention. German laws therefore incorporate analogous provisions to that of the UK where ratification of UNCAC has taken place. For example, active and passive bribery, bribery of foreign officials, extraterritorial reach, amongst others, are all evident. In this sense, non-ratification of the UNCAC in Germany has not made any significant difference to the policy response and enforcement context when contrasted with the UK, although the 'functional equivalence' approach of the OECD Convention does enable significant differences to remain between the UK and Germany in the legal frameworks. However, non-ratification of the UNCAC may create difficulties in mutual legal assistance should German authorities require cooperation with those jurisdictions that have not ratified the OECD Convention.

\section{Enforcing the law}

The particular nature of transnational corporate bribery poses identical problems to both jurisdictions. Transnational corporate bribery is clandestine and frequently involves consenting actors whereby both parties benefit from the corrupt transaction. The lack of identifiable consequences (e.g. no direct victims or harms), the 'invisibility' of actors, their 
relations and transactions due to the ambiguous nature of bribes (e.g. exchange of legitimate services) and the knowledge and power problems of the state ensuring corporate subsystems and their transactions remain difficult to access and understand (see Mayntz, 1993; Gill, 2002), are common characteristics of the problem in the UK and Germany. The following section evidences how responding to such a complex crime encounters structural, legal, evidential, procedural and financial obstacles and thus influences the ability of nationstates to enforce the international frameworks they have been pressured into implementing, even when resources and political will may be evident.

Structural: centralised vs. decentralised enforcement systems

Two diverse enforcement systems exist in the UK (centralised) and Germany (decentralised) which reflects geographical, historical and cultural factors but both reflect traditional 'command and control' regulatory regimes (see Baldwin and Cave, 1999). In 2005 the Serious Fraud Office (SFO) became the lead agency in the UK for investigating and prosecuting transnational bribery and corruption. ${ }^{6}$ Prior to this, these responsibilities were with an extraordinary number of state agencies including the SFO, the National Criminal Intelligence Service, the 43 local police forces (Metropolitan Police Service in particular), the City of London Police, the Ministry of Defence Police and the Companies Investigation Branch of the Department for Trade and Industry (now the Department for Business, Innovation and Skills). The SFO now has national jurisdiction (excluding Scotland) and receives support if and when required from the Overseas Anti-Corruption Unit of the City of London Police and the various local police forces. The Financial Services Authority (FSA) is 
also able to sanction regulated financial institutions for failures in anti-bribery and corruption compliance ${ }^{7}$ while the Ministry of Defence Police replaces the Overseas AntiCorruption Unit of the City of London Police if the case involves allegations against Ministry of Defence employees or defence contracts to which the Ministry of Defence is a party. Similarly, the Police Service for Northern Ireland replaces the Overseas Anti-Corruption Unit of the City of London Police if the case relates to Northern Ireland. The Crown Prosecution Service prosecutes any case not falling within the remit of the SFO, and Serious Organised Crime Agency has special investigatory powers to support SFO investigations and may also investigate a case if not accepted by the SFO.

Within the sixteen German Bundesländer (federal states), there are around 110 Staatsanwaltschaften (Public Prosecutor's Offices). Within each Bundesland there are a number of public prosecutor's offices, a Landeskriminalamt (State Criminal Investigation Office) and numerous Polizeipräsidien (Local Police Headquarters). The public prosecutors lead all transnational bribery and corruption cases and are supported by regional and local police during investigations. As in the UK, the German public prosecutor's office is involved in investigation and prosecution throughout the case and often conducts interrogations, analysis of documents, etc. without police assistance - this dual role of investigation and prosecution is a key commonality in the policing of serious and complex crimes such as transnational bribery. The police only become involved when directed to do so by the public prosecutor, while the Bundeskriminalamt (Federal Criminal Police Office) can facilitate investigations at the national level. Corruption and bribery only began to be substantially prosecuted following the creation of the first Schwerpunktstaatsanwaltschaften (prosecutor's offices with a special competence, in this case in the area of corruption). Not 
all Bundesländer have such specialist offices, but all usually have specialist departments or units that deal exclusively with corruption and bribery.

There are strengths and limitations of both systems. The UK's centralised model enables a more consistent and coordinated regulatory approach. However, the SFO has modest personnel and funding for an agency with national jurisdiction and therefore applies discretionary 'acceptance criteria' to all cases from the pre-investigation stage. ${ }^{8}$ This results in only large, complex cases being taken on - it has never been the case in England that the authorities are obliged to prosecute all the offences that come to their attention (Spencer, 2002: 161). In Germany, a more rigid legal framework exists which stipulates that prosecution of an offence is mandatory for public prosecutors and investigations must be commenced when sufficient suspicion arises (Juy-Birmann, 2002).

Despite this formal contrast, there is little difference between the two jurisdictions in the use and availability of discretion to determine whether or not to investigate or prosecute transnational bribery cases as similar consideration is given to public interest, likelihood of conviction, available resources and prioritisation. Legal alternatives are also available in both jurisdictions while the innovative use of the statute of limitation in Germany (five years) is also used. Thus, much convergence is evident despite contrasting legal traditions. For example, cases involving 'facilitation payments' ('grease payments') are unlikely to be prosecuted by the SFO and are subsequently accommodated by enforcement agencies - focus is instead placed on corporations to eradicate such payments within and by their organisations over time. In Germany, levels of enforcement vary across the Bundesländer as the extent of funding, political will and prosecutorial and investigatory expertise differs in each state. Some Bundesländer are significantly more 'enthusiastic' and this can lead to public prosecutors in some jurisdictions preferring to keep ownership over 
cases instead of passing them on to other authorities due to concerns that the case will not be intensively pursued. However, as responsibility lies with a multitude of actors and departments across the 16 Bundes/änder, the central state is less able to impart one-sided and partial procedures. Centralised enforcement in Germany is impracticable due to the historical, geographical and cultural development of the federal states: each Bundesland has a number of small, medium and large cities and municipalities, each with decision-making powers with which the Bundesland, or even the central-state, cannot always interfere. This creates a number of obstacles to reorganising the system and poses concerns for representatives of intergovernmental organisations such as the OECD and GRECO who are unable to ensure harmonised enforcement throughout Germany.

Legal: corporate criminal liability

Corporate criminal liability determines whether 'legal persons' (that is, corporations) can be prosecuted under the criminal law in the same way that 'natural persons' (individual persons) can be prosecuted although there is often some relationship between the two:

$[w]$ hen offences by individuals occur in a corporate context, it may be because the company's policies, culture and ethos authorize, encourage, condone or tolerate the illegal behaviour...That the individual was committing the offence on behalf of a company provides a handy rationalization for the crime.' (Gobert, 2011: 154)

Corporate criminal liability in the UK has traditionally required courts to locate the corporate mind for purposes of assessing mens rea. English judges found the 'company's 
mind' in the mind of persons who could be 'identified' with the company for legal purposes (Gobert and Punch, 2003: 38). This historical focus on the individual has caused the legal mind to struggle with locating mens rea in an aggregate entity (Punch, 2011: 111). This has remained a key difficulty in the UK:

\footnotetext{
I mean the major problem remains that we have horrendously bad corporate liability laws. If companies are a little bit clever and export their corruption to foreign commission agents they can distance themselves sufficiently far from it so as to keep the controlling mind well out...The only reason smaller companies like Mabey and Johnson ${ }^{9}$ got done is the directors are actually doing the work - the controlling mind -, are actively involved in the work (Interview with UK prosecutor)
}

The difficulty in locating the 'controlling mind' remains for the general offences of active and passive bribery (this influences the increased use of civil approaches in the UK). However, under the corporate offence of 'failure to prevent bribery' (section 7 UKBA) a corporation can also be held criminally liable for acts of bribery by its associated persons (employees, subsidiaries, intermediaries, sales agents, and so on) that are carried out on behalf of the corporation. Previous to the UKBA, and as above, corporations could only be held criminally liable if it could be proved that the 'corporate mind' (i.e. a board member or executive) had a direct role in the bribery. However should the UK corporation have 'adequate' anti-bribery procedures, policies and cultures in place, this may provide a legal defence to prosecution. The inclusion of a form of strict liability into the UKBA reflects the argument that ' $[\mathrm{t}]$ he organization often provides the motive, opportunity and means; it is the scene of crime; and the offences can be committed across time and in diverse locations depending on the structure of the company' (Punch, 2011: 110) (emphasis added). 
However, such strict liability removes the requirement of intent and may reinforce such behaviour as 'mala prohibita' rather than 'mala in se'.

Corporations in Germany cannot be held criminally liable. The distinction between 'legal persons' and 'natural persons' has more meaning here as what a corporation does cannot be interpreted as an 'act' in German Penal Law (Hefendehl, 2001):

The German system is based on the principle of guilt, and only someone considered a natural person can have guilt. A legal entity is an empty body and only the person able to act for the entity can realise this guilt. (Interview with German lawyer)

Consequently, only 'natural persons' can be held criminally liable. The responsibility of legal persons and associations of persons is regulated by the law for violations of good order, or in other words, regulatory offences (Rogall, 2011: 334). Thus, liability may be imposed on corporations by state authorities only for administrative offences (Ordnungswidrigkeiten) which result only in administrative fines (Geldbuben). The prerequisite is that as a result of the criminal offence, the company's duties have been violated or the company has been enriched or intended to be enriched. Additionally, in cases where a company's management has taken inadequate supervisory measures required to prevent bribery, the company may be held liable. For example, section 130 'Violation of obligatory supervision in firms and enterprises' of the Administrative Offences Act (Gesetz über Ordnungswidrigkeiten) relates to violations of supervisory duties as a result of failures by senior officers of the company to supervise employees if their actions led to criminal or administrative offences. This offence brings a maximum fine of $€ 1 \mathrm{~m}$ plus 
unlimited confiscation of profits made from the bribery. However, a lack of corporate criminal liability is not necessarily a problem for intergovernmental organisations:

I don't really care whether Germany has a genuinely criminal concept or a para-criminal concept; that doesn't matter very much. I find a million Euros [maximum administrative fine for the offence] is too little and in the [name of organisation] context, it is on the lower side. I am not unhappy in the way that they apply it - on corruption they have done quite a lot in the meantime. (Interview with intergovernmental organisation representative)

This reflects the 'functional equivalence' position of intergovernmental organisations that places emphasis on successful outcomes of bribery cases as opposed to harmonisation of the mechanisms adopted to investigate and prosecute although some criticism of the penalties is evident. While such divergence at the national level may be acceptable by intergovernmental organisations, it can potentially create difficulties in Mutual Legal Assistance (Rechtshilfe (MLA)). In other words, some jurisdictions may be unable to assist where there is no criminal law element involved, and difficulties in terms of debarment Article 45 of the EU Procurement Directive ${ }^{10}$ requires mandatory debarment of corporations criminally prosecuted for bribery, but this is not possible in Germany. Although judges are able to debar German corporations independently, this has yet to occur. This creates the potential for an 'uneven playing field'.

Evidential: transnational investigations

Evidential difficulties are most notable in two ways: (i) the burden of proof when attempting to criminally prosecute a corporation and (ii) obtaining evidence from other jurisdictions. A 
recent example of these difficulties in the UK can be seen in the case involving Oxford Publishing Ltd (OPL), a wholly owned subsidiary of Oxford University Press (OUP). OPL received sums generated through corrupt behaviour in Kenya and Tanzania and on 3 July 2012 were given a Civil Recovery Order. The rationale for not pursuing criminal prosecution were that (i) key material obtained through the investigation was not in an evidentially admissible format for a criminal prosecution and that (ii) witnesses in any such prosecution would be in overseas jurisdictions and are considered unlikely to assist or co-operate with a criminal investigation in the UK. ${ }^{11}$

Considering such obstacles along with the difficulties of locating the 'controlling mind' of a corporation, as above, demonstrates key limits to prosecution policies. For example, determining accountability and/or proving a director or executive of a corporation was involved in the bribery is complex. The size and scope of a corporation influences director accountability as devolved decision making processes, issues of implied consent, 'corporate cultures' and various other structural complexities within MNCs make links between a corporation's and director's actions difficult to detect and prove. For example, top-down pressure from high-level executives and managers to maximise turnover and profits may create a culture that encourages or legitimises bribery but evidencing the relationship between executive pressure and acts of bribery by employees cannot easily be proved. This is further complicated within corporations where various levels of hierarchy and responsibility are evident or where foreign subsidiaries and associates are involved. Obtaining evidence to support investigations for both the purposes of ascertaining individual and corporate liability and for investigations generally is further complicated by the transnational nature of corporate bribery. For example, how does a UK/German prosecutor obtain evidence in a bribery case when the bribes were given by an agent based 
in African country A, who was employed by company $Z$ that is based in Asian country $B$, and who is connected to the UK/Germany as it is the subsidiary of company $Y$ based in London/Frankfurt (country C)? These distant relationships between agents and clients, the high level of secrecy and privacy or lack of direct victims to report, and differing laws in different countries create major problems - the nature of global business transactions creates a significant barrier to effective regulation and enforcement (Gibbs et al, 2010: 550). Both UK and German prosecutors are faced with these difficulties. It may be that proving the transaction is more straightforward than proving what the benefit was. For example, money changing hands in unusual circumstances or wrongly accounted for transactions in difficult to trace bank accounts using front companies are usually recorded somewhere. Proving the benefit, or the trade-off, is more complex, as it may be an inducement or a reward with no written record, making a clear understanding and a fortiori proof of that understanding more difficult. Gathering evidence on such cases requires MLA.

Investigators and prosecutors, in all transnational corporate bribery cases, must cooperate with agencies in other jurisdictions in order to ascertain information and evidence but the efficacy of MLA varies significantly in different countries. For example, although the German authorities have excellent relations with neighbouring countries such as Austria and Switzerland, difficulties often emerge further afield. As one German investigator explained:

With some countries it fails due to their biography, with some due to the resources as the capacity is simply not there. Sometimes it is the case that there's no evident will to assist, and then there are those countries where you can really say that there are national authorities with which you're not even allowed to try to cooperate. It varies a lot. (Interview with German investigator) 
Difficulties exist even between the UK and Germany, as while they have worked effectively together, language difficulties can emerge (German prosecutors are often fluent in English but this is less frequently the case further down the enforcement regime and the SFO has minimal foreign language expertise) which requires employing interpreters and translators at high cost. One UK investigator talked of some individuals advocating automated translation but he (understandably) did not appear convinced about the standard of English that came out of this. Further difficulties arise when requesting assistance from developing countries, in other words, from those countries with inadequate anti-bribery and corruption enforcement systems and those with insufficient resources to ratify international enforcement frameworks.

Some countries have been notoriously difficult to obtain information from making MLA time consuming. The anonymity involved in international commerce via numerous financial institutions and through difficult to access jurisdictions causes great difficulties for regulation (Elliot, 2009). Some jurisdictions, for example Lichtenstein, Switzerland and Luxembourg, amongst others, have traditionally had very stringent secrecy laws and provisions in relation to the banking system, making obtaining information about financial transactions and bank accounts more difficult. One UK investigator gave the example of an individual in Switzerland having seventeen separate opportunities to appeal against material being transferred to the UK. Other countries may have different procedures, for example, only cooperating via formal written requests rather than giving prior information via a simple telephone call, as it goes against their legal system based on Commissions Rogatoires between judicial authorities, not the police. In another case, the French authorities complained that a search conducted for them in the UK was of no use because all the UK 
authority had done was send them the original documents that were confiscated - as no investigator's report was attached outlining the nature of the MLA request, they were not able to use it under their system. This can make cooperation long-winded despite speed being of paramount importance in some cases. However, one UK investigator suggested that in the view of other European countries, the UK does not have a good reputation for MLA - a view substantiated by some German prosecutors and investigators (See also Levi (1987) showing this is not a recent phenomenon). Even more difficult is cooperation with those countries that have no anti-bribery and corruption authorities or no political will to assist. These factors reinforce limited enforcement models at the national level and the difficulties in implementing international frameworks for enforcement. However, recent global settlements between the UK and the US, and between Germany and the US, have demonstrated how MLA can work effectively and attempt to address this transnational difficulty. ${ }^{12}$

Procedural: prosecution policy

Conducting transnational investigations and prosecutions is resource intensive. Criminal prosecution is extremely expensive and time-consuming due to the high costs of investigation to meet the substantial evidential and procedural requirements (as above), due to the costs of recruiting external counsel and prosecutors for large complex cases, and due to the ability of corporations to employ technical and expert legal teams to defend them all of which lower the likelihood of conviction. Conversely, civil solutions are more cost effective, with corporations often covering the costs of investigation. Civil solutions enable the prosecutorial authorities to conclude an increased number of cases as there is no 
requirement to prove a criminal offence and the burden of proof is lower therefore increasing the likelihood of a successful outcome. This in turn enables the authorities to extend their reach. Civil solutions to this can take several forms: financial settlements and fines; restitution via Civil Recovery Orders that include the amount of the unlawful property (for example, often profits from contracts won), and investigatory and prosecutorial costs. In relation to the demand for resources and the use of civil solutions for overseas bribery cases, one UK prosecutor stated:

\footnotetext{
...that doesn't mean that they are any less criminal [companies that bribe compared to 'conventional criminals'], it just means that you are trying to bring them to justice in a way that doesn't sap all of your resource because obviously we are having our budgets cut quite drastically. So it is an extremely efficient way if they come to you and report and then correct the problem which is part of the solution, isn't it. (Interview with UK prosecutor)
}

In the current economic climate, particularly in the UK, available resources are influencing the adoption of more cost-effective approaches. The SFO has had its budget reduced in recent years. In Germany, resources are more widely available but the decentralised system results in some prosecutors being better equipped than others. Noncriminal approaches may also be preferred due to the risk of debarment under the abovementioned EU Directive that requires mandatory debarment of any corporation found guilty of a corruption offence. The financial consequences of debarment to a country's economy can be significant, causing tension for states between considering national economic interest and ensuring the Rule of Law.

Thus, UK and German investigators and prosecutors, as well as representatives of intergovernmental organisations, accept the reality of financial, evidential and procedural 
restraints but this shift towards civil solutions is also ideological and symbolic as these actors suggest that much corporate, economic crime requires negotiation and persuasion rather than criminal prosecution as part of a more dynamic approach. For example, new regulatory models include 'responsive regulation' (Ayres and Braithwaite, 1992), 'smart regulation' (Gunningham and Grabosky, 1998), problem-solving regulation (Sparrow, 2008), 'metaregulation' (Parker, 2002), market based regulation (Gill, 2000; Edwards and Gill, 2002), the 'governance triangle' (Abbott and Snidal, 2006), 'regulatory capitalism' (Braithwaite, 2008) and 'really responsive risk-based regulation' (Black and Baldwin, 2010) while there has been recent focus on regulators as 'sociological citizens' (Silbey et al., 2009; Silbey, 2011). Multiple common themes can be seen throughout these approaches. For example, the need for a varied set of sanctions and strategies including both enforcement and self-regulatory mechanisms, the necessity of 'negotiated relationships' between the regulators and regulatees, the reflexivity, responsiveness and agency of the regulators, and the involvement of non-state actors and agencies. As Haines notes:

This literature places the regulator within a broad governance framework where the enforcement of rules within narrow prescriptive frameworks is eschewed in preference for policy mixes, combining instruments, third-party actors, and enforcement regimes that collectively can both "push" and "pull" (Gunningham and Grabosky, 1998: 259) regulatees into a reflexive appreciation of the goals the regulator wants to achieve and lead them to act in a diligent manner to bring the goals to fruition' (Haines, 2011: 118-119)

In line with these new regulatory models, innovative and parsimonious approaches have emerged within the regulatory landscape of transnational corporate bribery. 'Hybrid mechanisms' such as the use of self-reporting, self-cleaning ${ }^{13}$ and self-investigation, 
amongst others, have formed part of civil settlements. An SFO press release described this new approach as being 'more effective and costing less' and resulting in the SFO becoming 'stronger, faster and leaner' ${ }^{14}$. However, in October 2012, the new Director, David Green, attempted to 'toughen' the SFO's stance towards bribery by removing previous guidance on self-reporting that indicated likely incentives to corporations and by reaffirming the role of the SFO as a prosecutor - given the difficulties to prosecution outlined above, this may prove to be rhetorical. However, the likely introduction of Deferred Prosecution Agreements (DPAs) in 2013 in the UK may provide the SFO with a further innovative mechanism that can enable the SFO to both reinforce its prosecutorial role while continuing to shift towards 'negotiated justice'. In Germany prosecutors are already adopting non-prosecution agreements as a way of addressing evidential difficulties. Given the multi-jurisdictional nature of overseas bribery, prosecutors may also attempt to offer finality to the corporation by reaching global settlements with other jurisdictions. It has been argued that such shifts away from criminal prosecution may provide a more suitable enforcement framework: Khanna concludes that

...if we start with the notion that corporate wrongdoing is not sufficiently deterred at present, then we would want to argue for curtailing corporate criminal liability and increasing the focus on corporate civil liability and managerial liability. This raises serious questions about how we regulate this area. (2004: 141, emphasis in original)

Khanna's argument is based on the premise that corporate crime legislation may be the preferred outcome for corporate interests as it (i) satisfies public outcry but (ii) imposes low costs on businesses, and (iii) therefore avoids legislative and judicial responses that are 
more harmful to their interests and sometimes deflects criminal liability away from managers and executives and onto corporations (2004: 95). However, Wells does not believe anyone seriously suggests private law as the only option as even Khanna emphasises the importance of public enforcement (2011: 15). Shifts towards non-criminal alternatives may also reduce the stigma associated with such criminal behaviour and fail to satisfy public demand for social fairness and retribution, creating an image of such offences as 'mala prohibita' rather than 'mala in se'.

\section{Implications for the policy response}

The complex organisation of corporate bribery presents obstacles to prosecution and conviction, rendering criminal law enforcement implausible in the current control landscape - the difficulties when criminally prosecuting corporations, the shift towards civil settlements and negotiation, the need to use resources effectively, the evidential burdens of transnational investigations, etc. inhibit the policy response of the UK and Germany to address transnational bribery. Although some regulation is possible, the enforcement capacities of responsible agencies and actors cannot meet even the most conservative estimate of the 'need' or 'demand' for prosecutions, even more so in times of austerity.

Understanding these limitations may assist policymakers, legislators and agents of control in improving current practices. Granted that there may be a demand for punishing bribery as just deserts and social fairness, irrespective of the deterrent impact, other approaches are possible either as substitutes or as supplements. Shifting analytical focus onto the modus operandi of how those incidents of bribery (that do come to the attention of the authorities and are successfully prosecuted) have been organised and onto the 
particular technical and social characteristics and relations of transnational bribery would supplement more reactive policies. For example, white-collar crime reduction has been analysed through an 'opportunity perspective' approach, the tools of which are predominantly situational crime prevention, routine activities theory and crime pattern theory (see Benson et al., 2009; Benson and Simpson, 2009). Based on the 'crime triangle' (i.e. motivated offender, opportunity and capable guardians), the propensity to commit offences is assumed and analytical focus is placed on 'opportunity structures'. By identifying the features of the immediate 'situations' within which white-collar crimes take place and the processes involved, it is possible to intervene and reduce (or perhaps displace) such crimes. Understanding the 'technical' dimensions of corporate bribery is clearly important for enforcement authorities. However, such approaches must be supplemented with an understanding of the 'social' dimensions (i.e. the necessary and contingent relations (see Edwards and Hughes, 2005) of corporate bribery and the nature of these relations in different geo-historical contexts). Intervention strategies incorporating both dimensions guided by risk-based assessments of potentially corruptible markets, sectors, corporations and individuals can strategically shape the enforcement response. For example, drawing on Levi's process model of transnational 'serious crimes' (2007: 781), enforcement agencies could aim to develop intervention points in relation to the following processes and characteristics, amongst others, that incorporate both technical and social dimensions and risk assessments:

1. How are the finances for bribes obtained? For example, how do legitimate corporations channel funds for the creation of slush funds and what are the 
concealment practices involved? E.g. use of front companies; fake conferences to generate funds; inflated prices.

2. How are bribe payers and receivers recruited (e.g. internal/external, domestic/overseas to the corporation) and how do they develop the expertise/technical ability to develop bribery schemes? Which criteria identify potential intermediaries and bribe receivers e.g. politicians, state officials?

3. Which corporate mechanisms and tools are utilised and necessary to be able to bribe? E.g. bank accounts in difficult to reach jurisdictions. How are the proceeds of bribes concealed and converted (i.e. money laundering) from the various authorities (e.g. law enforcement, tax authorities) and what are the particular legal/structural contexts that enable this?

4. Which jurisdictions, which industries/sectors (e.g. construction, pharmaceutical, manufacturing) and which corporate employees (e.g. sales agents, middle-level managers) are at highest risk of bribery and how can this risk be located within specific geo-historical contexts?

5. Which external and internal actors are required to be complicit for bribery to remain undetected and how are these relations developed over time? E.g. external accountants, high-level management.

6. How might bribe givers neutralise law enforcement responses and/or 'capable guardians'?

Understanding the necessary and contingent relations of bribery enables key vulnerabilities in the above processes to be determined for strategic interventions, even if it may not be possible in the short term politically to close off those loopholes. Law 
enforcement agencies, however, are under pressure to produce 'results', usually in the form of prosecutions, in order to ensure they maintain their existence and function. Shifts towards prevention and disruption reduce the number of measureable results but may also contradict statutory remits, most notably in Germany:

Prevention is something that the public prosecutor doesn't do. We only operate in terms of repression...By law we are explicitly a prosecutorial authority. We have no mandate for prevention. (Interview with German prosecutor)

However, law enforcement agencies must incorporate more innovative intervention strategies beyond traditional reactive enforcement mechanisms of criminal prosecution if the behaviour of corporations is to be changed. 'Hybrid mechanisms' such as self-reporting by corporations and self-cleaning, as above, are a key shift in this direction. Other potential practices such as improved whistleblowing provisions (although American-style financial rewards for 'high-quality' tips as with the Dodd-Frank Act may contradict and undermine corporate anti-bribery policies) and certification schemes (providing these do not conflict with the ability to prosecute and sanction corporations) require consideration but such mechanisms are shaped within the constraints of legal cultures and jurisdictional boundaries. There is, however, much scope for innovation at the multi-jurisdictional, transnational level - coordinated risk-based intervention strategies between anti-corruption agencies and actors in different jurisdictions offers much potential but remains politically and legally difficult. Intergovernmental organisations such as the GRECO, the OECD and the UN do generate themed reports across jurisdictions and provide frameworks for coordinated approaches but joint prevention/proactive exercises are not institutionally 
possible except via industry initiatives. For example, UK and German authorities could in coordination target high-risk sectors (e.g. manufacturing, defence) or high-risk jurisdictions (e.g. corporations operating in a particular country where corruption remains problematic) in raids, but there is currently no obvious prevention mechanism or legislative powers for so doing in advance of criminal complaints.

\section{Conclusion}

International frameworks for enforcement pressure nation-states to sign and ratify their requirements leading to implementation at the national level. Comparison of two theoretically comparable anti-corruption systems, the UK and Germany, enables significant insights into the impact of these international legal frameworks at the national level. First, such frameworks lead to legal convergence at the national level in relation to specific provisions accounting for bribery of foreign officials. Thus, harmonisation of the law is evident (despite Germany not having ratified the UNCAC). However, significant differences remain in these jurisdictions. Second, the enforcement of such legal frameworks at the operational level is the key issue. Whether centralised or decentralised and irrespective of other differing characteristics (for example, corporate criminal liability) enforcement systems at the national level face significant difficulties. The moral and socio-economic harms of corruption have led concerned parties to focus on law enforcement and other control mechanisms but criminal justice mechanisms have not proven to be easy, even when motivation to enforce is high. The law provides a normative framework within which 
certain activities have been condemned. The criminal law framework therefore remains significant for prosecutors for its symbolic and (potentially) deterrent effect in order for the state (i) to negotiate regulation with corporations and (ii) to demonstrate to the various publics at the national, regional and international levels that it is actively enforcing the law against corporations that bribe overseas.

Law enforcement, however, faces structural, legal, evidential, procedural and financial obstacles. The 'functional equivalence' approach of intergovernmental organisations enables diversity in the 'means' adopted providing the 'goals' (in other words, the successful conclusion of bribery cases) are met. This can be seen in relation to corporate criminal liability that is legally available in the UK but not in Germany. That said, other obstacles (for example, high burden of proof and financial costs of criminal prosecution) and/or ideologies (for example, regulatory approaches favouring compliance and persuasion rather than prosecution of corporations) have led to convergence in the regulatory approaches of these two jurisdictions. For example, corporations bribing overseas are likely to be able to negotiate civil solutions (to criminal behaviours) that incorporate financial penalties and more innovative mechanisms such as self-cleaning, monitoring and introducing adequate compliance systems to reduce the likelihood of future bribery. Thus, responding to transnational corporate bribery using international frameworks for enforcement, while legally sound, is not entirely practicable as difficulties emerge that hinder the full use of these legal provisions.

\section{Acknowledgements}




\section{Notes}

${ }^{1}$ The UK-Saudi Arabia Al-Yamamah arms deal involved allegations of bribes paid to Saudi Officials by BAE totalling more than $f 1 b n$. An SFO investigation was halted in 2006 following government pressure. Tony Blair alluded to national security fears. In 2010, the SFO agreed a 'plea-bargain' with BAE in relation to other accusations of bribery in Tanzania, although BAE admitted only to relatively minor accounting offences and not bribery. The Siemens scandal involved a system of slush funds used to pay bribes to win overseas contracts. To date, Siemens has paid a total of $€ 2.5 \mathrm{bn}$ to various agencies in administrative fines while a number of managers were convicted.

${ }^{2}$ See Transparency International's discussion of 'costs of corruption':

http://archive.transparency.org/news room/faq/corruption faq\#faqcorr4 (accessed 6 September 2012)

${ }^{3}$ Although the 'UK' is used, this article refers specifically to England and Wales, and Northern Ireland Scotland is not included here as it constitutes a separate jurisdiction in relation to transnational corporate bribery (and other offences).

${ }^{4}$ Full report available at:

http://issuu.com/transparencyinternational/docs/2012 exportingcorruption oecdprogress en?mode=windo w\&printButtonEnabled=false\&shareButtonEnabled=false\&searchButtonEnabled=false\&backgroundColor $=\% 23$ 222222 (accessed 6 September 2012)

${ }^{5}$ For discussion see - GRECO (2009) Third Round Evaluation on Germany (see paragraphs 37 et seqq. and 106 et seqq.):

http://www.coe.int/t/dghl/monitoring/greco/evaluations/round3/GrecoEval3\%282009\%293 Germany One E N.pdf (accessed 6 September 2012)

${ }^{6}$ See 'Revised Memorandum Of Understanding On Implementing Part 12 Of The Anti-terrorism, Crime And Security Act 2001': http://www.parliament.uk/deposits/depositedpapers/2008/DEP2008-0269.pdf (accessed 6 September 2012)

${ }^{7}$ In the Aon Ltd case, the company was fined for failing to take reasonable care to establish and maintain effective systems and controls to counter the risks of bribery and corruption. FSA press release: http://www.fsa.gov.uk/pages/Library/Communication/PR/2009/004.shtml (accessed 6 September 2012) ${ }^{8}$ SFO criteria:

http://www.sfo.gov.uk/fraud/report-it-in-confidenceanonymously/serious-fraud-office-\%28sfo\%29criteria.aspx (accessed 6 September 2012)

${ }^{9}$ Mabey and Johnson, a supplier of steel bridging, pleaded guilty to bribing overseas officials in relation to public contracts - SFO press release: http://www.sfo.gov.uk/press-room/latest-press-releases/press-releases2009/mabey--johnson-Itd-sentencing-.aspx (accessed 6 September 2012)

${ }^{10}$ Full text of the Directive: http://eurlex.europa.eu/LexUriServ/LexUriServ.do?uri=CELEX:32004L0018:En:HTML (accessed 6 September 2012)

${ }^{11}$ SFO press release: http://www.sfo.gov.uk/press-room/latest-press-releases/press-releases-2012/oxfordpublishing-Itd-to-pay-almost-19-million-as-settlement-after-admitting-unlawful-conduct-in-its-east-africanoperations.aspx (accessed 6 September 2012)

${ }^{12}$ The Innospec case involved a global settlement between US and UK authorities; the Siemens case involved intense cooperation between the Munich prosecutors and US authorities.

${ }^{13}$ Self-cleaning involves clarification of the relevant facts and circumstances; repair of the damage caused; personnel measures; and, structural and organisational measures by the corporation (see Arrowsmith, et al., 2009)

${ }^{14}$ SFO press release: http://www.sfo.gov.uk/press-room/latest-press-releases/press-releases-2011/seriousfraud-office---more-effective-and-costing-less.aspx (accessed 6 September 2012)

\section{References}


Abbott K and Snidal D (2006) The Governance Triangle: Regulatory standards institutions and the shadow of the state. Working Paper, Global Governance Project, Oxford University.

Arrowsmith S, Priess H-P and Friton P (2009) Self-cleaning as a defence to exclusions for misconduct: an emerging concept in EC public procurement law? Public Procurement Law Review 6: 257-282.

Ayres I and Braithwaite J (1992) Responsive Regulation: Transcending the Deregulation Debate. New York: Oxford University Press.

Baldwin R and Cave M (1999) Understanding Regulation. Theory, Strategy, and Practice. Oxford: OUP.

Black J and Baldwin R (2010) Really responsive risk-based regulation. Law and Policy 32(2): 181-213.

Braithwaite J and Drahos P (2000) Global Business Regulation. Cambridge: CUP.

Braithwaite J (2008) Regulatory Capitalism: How it works, ideas for making it work better. Cheltenham: Edward Elgar.

Delaney PX (2007) Transnational Corruption: Regulation Across Borders. Virginia Journal of International Law 47(2): 413-461.

Edwards A and Gill P (2002) Crime as enterprise? The case of "transnational organised crime". Crime, Law and Social Change 37: 203-223.

Edwards, A and Hughes, G (2005) Comparing the Governance of Safety in Europe: A geo-historical approach. Theoretical Criminology 9(3): 345-363. 
Elliot L (2009) Combating transnational environmental crime: "Joined up" thinking about transnational networks. In: Kangaspunta K and Marshall IH (eds) Eco-Crime and Justice: Essays on Environmental Crime. Turin, Italy: Public Information Department UNICRI.

Gibbs C, McGarrell EF and Axelrod M (2010) Transnational white-collar crime and risk: Lessons from the global trade in electronic waste. Criminology and Public Policy 9(3): 543-560.

Gill P (2000) Rounding Up the Usual suspects? Developments in contemporary law enforcement intelligence. Aldershot: Ashgate Publishing Ltd.

Gill P (2002) Policing and Regulation: What is the difference? Social and Legal Studies 11(4): 523-546.

Gobert J and Punch M (2003) Rethinking Corporate Crime. London: Butterworths.

Gobert J (2011) Squaring the circle. The relationship between individual and organizational fault. In: Gobert J and Pascal A-M (eds) European Developments in Corporate Criminal Liability. London: Routledge.

Gunningham N and Grabosky P (1998) Smart Regulation: Designing Environmental Policy. Oxford: Clarendon Press.

Haines F (2011) Addressing the risk, reading the landscape: The role of agency in regulation. Regulation and Governance 5(1): 118-144.

Hefendehl R (2001) Corporate Criminal Liability: Model Penal Code Section 2.07 and the Development in Western Legal Systems. Buffalo Criminal Law Review 4(1): 283-300.

Juy-Birmann R (2002) The German system. In: Delmas-Marty M and Spencer JR (eds) European Criminal Procedures. Cambridge: CUP. 
Khanna VS (2004) Corporate Crime Legislation: A Political Economy Analysis. Washington University Law Quarterly 82: 95-141.

Levi M (1987) Regulating Fraud. London: Tavistock.

Mayntz R (1993) Governing Failures and the Problem of Governability. In: Kooiman J (ed.) Modern Governance: New Government-Society Interactions. London: Sage.

Michalowski R and Bitten K (2005) Transnational environmental crime. In: Reichel P (ed.) Handbook of Transnational Crime and Justice. Thousand Oaks, CA: Sage.

OECD (1997) Convention On Combating Bribery Of Foreign Public Officials In International Business Transactions. Available at: http://www.oecd.org/dataoecd/4/18/38028044.pdf (accessed 6 September 2012).

Parker C (2002) The Open Corporation: Self-Regulation and Corporate Citizenship. Melbourne: Cambridge University Press.

Passas N (1999) Globalization, Criminogenic Asymmetries and Economic Crime. European Journal of Law Reform 1(4): 399-423.

Punch M (2011) The organizational component in corporate crime. In Gobert J and Pascal A-M (eds) European Developments in Corporate Criminal Liability. London: Routledge.

Rogall K (2011) Country report: Germany. In: Gobert J and Pascal A-M (eds) European Developments in Corporate Criminal Liability. London: Routledge. 
Rose-Ackerman S (1997) The Political Economy of Corruption. In Elliot KA (ed.) Corruption and the Global Economy. Washington, DC: Institute for International Economics.

Shover N and Hochstetler A (2006) Choosing White-Collar Crime. Cambridge: CUP.

Silbey SS, Huising R and Coslovsky S (2009) The Sociological Citizen: Recognizing Relational Interdependence in Law and Organizations. L'Année Sociologique 59: 201-229.

Silbey SS (2011) The Sociological Citizen: Pragmatic and relational regulation in law and organizations. Regulation and Governance 5(1): 1-13.

Snider $L$ and Bittle S (2011) The challenges of regulating powerful economic actors. In: Gobert J and Pascal A-M (eds) European Developments in Corporate Criminal Liability. London: Routledge.

Sparrow MK (2008) The Character of Harms. Operational Challenges in Control. Cambridge: Cambridge University Press.

Spencer JR (2002) The English system. In Delmas-Marty M and Spencer JR (eds) European Criminal Procedures. Cambridge: CUP.

Wells C (2011) Containing corporate crime. Civil or criminal controls? In Gobert J and Pascal A-M (eds) European Developments in Corporate Criminal Liability. London: Routledge.

Wolf S (2006) Modernization of the German Anti-Corruption Criminal Law by International Legal Provisions. German Law Journal 7(9): 785-792. 